\title{
ON THE REFINEMENT OF QUANTUM HERMITE-HADAMARD INEQUALITIES FOR CONTINUOUS CONVEX FUNCTIONS
}

\author{
Julalak Prabseang, Kamsing Nonlaopon and Sotiris K. NTOUyas
}

Abstract. The purpose of this paper is to establish some new refinement of quantum HermiteHadamard inequalities for continuous convex functions. Several known results are reduced as special cases.

Mathematics subject classification (2010): 26D10, 26D15, 26 A51. functions.

Keywords and phrases: Hermite-Hadamard inequality, $q$-derivative, $q$-integral, continuous convex

\section{REFERENCES}

[1] M. Alomari AND M. DARUs, Hadamard-type inequalities for s-convex functions, International Mathematical Forum, 3 (2008), 1965-1970.

[2] M. Alomari, M. Darus And S. S. Dragomir, New inequalities of Hermite-Hadamard type for functions whose second derivatives absolute values are quasi-convex, Tamkang J. Math., 41 (2010), 353-359.

[3] N. Alp, M. Z. SARIKAya, M. Kunt And İ. İşCAn, q-Hermite Hadamard inequalities and quantum estimates for midpoint type inequalities via convex and quasi-convex functions, J. King Saud Univ. Sci. doi:10.1016/j.jksus.2016.09.007.

[4] G. Bangerezako, Variational q-calculus, J. Math. Anal. Appl., 289, 2 (2004), 650-665.

[5] S. S. DRAGOMIR AND S. FitzPATRICK, The Hadamard inequality for $s$-convex functions in the second sense, Demonstr. Math., 32 (1999), 687-696.

[6] S. S. DRAGOMIR, On some new inequalities of Hermite-Hadamard type for $m$-convex functions, Tamkang J. Math., 33 (2002), 55-65.

[7] S. S. Dragomir, Two refinements of Hadamard's inequalities, Coll. of Sci. Pap. of the Fac. of Sci. Kragujevac (Yugoslavia), 11 (1990), 23-26.

[8] S. S. Dragomir, On Hadamard's inequalities for convex functions, Math. Balkanica, 6 (1992), 215222.

[9] S. S. Dragomir and C. E. M. Pearce, Selected Topics on Hermite-Hadamard Inequalities and Applications, RGMIA Monographs, Victoria University: Melbourne, Australia, 2000.

[10] T. ERnst, The history of q-calculus and a new method, Department of Mathematics, Uppsala University, Sweden, 2000.

[11] H. Gauchman, Integral inequalities in q-Calculus, Comput. Math. Appl., 47, 2-3 (2004), 281-300.

[12] J. HADAMARD, Etude sur les propriétés des fonctions entiéres et en particulier d'une fonction considérée par Riemann, J. Math. Pures Appl., 9 (1893), 171-216.

[13] C. Hermite, Sur deux limites d'une intégrale dé finie, Mathesis, 3 (1883), 82.

[14] D. A. Ion, Some estimates on the Hermite-Hadamard inequality through quasi-convex functions, An. Uni. Craiova Ser. Math. Inform., 34 (2007), 82-87.

[15] F.H. JACKSON, On a q-definite integrals, Quart. J. Pure Appl. Math., 41 (1910), 193-203.

[16] F.H. JACKSON, q-difference equations, Amer. J. Math., 32 (1910), 305-314.

[17] V. KaC And P. Cheung, Quantum Calculus, Springer, New York, 2002.

[18] H. Kavurmaci, M. Avci And M. E. ÖZdemir, New inequalities of Hermite-Hadamard type for convex functions with applications, J. Ineq. Appl., 2011 (2011), 86. 
[19] U. S. Kirmaci, M. Klaričić Bakula, M.E. Özdemir and J. PeČarić, Hadamard-type inequalities for s-convex functions, Appl. Math. Comput., 193 (2007), 26-35.

[20] Z. LiU, Generalization and improvement of some Hadamard type inequalities for Lipschitzian mappings, J. Pure Appl. Math. Adv. Appl., 1 (2009), 175-181.

[21] V. N. Mishra AND P. Patel, On Generalized integral Bernstein operators based on q-integers, Appl. Math. Comput., 242 (2014), 931-944.

[22] M. A. Noor, K. I. Noor And M. U. Awan, Some quantum estimates for Hermite-Hadamard inequalities, Appl. Math. Comput., 251 (2015), 675-679.

[23] M. A. Noor, K. I. Noor And M. U. Awan, Some quantum integral inequalities via preinvex functions, Appl. Math. Comput., 269 (2015), 242-251.

[24] J. Prabseang, K. Nonlaopon and J. TARiboon, Quantum Hermite-Hadamard inequalities for double integral and q-differentiable convex functions, J. Math. Ineq., 13 (2019), 675-686.

[25] W. Sudsutad, S. K. NTOUYAS AND J. TARiBoon, Quantum integral inequalities for convex functions, J. Math. Inequal., 9 (2015), 781-793.

[26] J. TARIBOON AND S. K. NTOUYAS, Quantum calculus on finite intervals and applications to impulsive difference equations, Adv. Difference Equ., 2013 (2013), 282.

[27] J. TARIBOON AND S. K. NTOUYAS, Quantum integral inequalities on finite intervals, J. Inequal. Appl., 2014 (2014), 121. 